\title{
Local finances in France: what place? What challenges?
}

\section{Finanse lokalne we Francji: jakie zajmują miejsce? Jakie wyzwania im towarzyszą?}

\begin{abstract}
The finances of local authorities in France have their origins in the French Revolution of 1789. At that time, local authorities were small and their finances too. Everything has changed from the 1980s. Since then, local finances have been a determining component of our public financial system and are even at the heart of current budgetary and fiscal challenges. They also integrate an efficient management of public funds from which the central government draws its inspiration.
\end{abstract}

Keywords: local authorities; reform of local taxation; State grants; public performance.

Streszczenie. Finanse władz lokalnych we Francji mają swoje korzenie w rewolucji francuskiej z 1789 roku. Samorządy lokalne posiadały wówczas niewielkie struktury, a więc dysponowały niewielkimi zasobami finansowymi. Od lat 80. ubiegłego wieku wszystko zaczyna się zmieniać. Odtąd finanse lokalne 
są decydującym elementem francuskiego publicznego systemu finansowego i znajdują się w centrum obecnych wyzwań budżetowych i fiskalnych. Towarzyszy im też efektywne zarządzanie funduszami publicznymi będące inspiracją dla rządu centralnego.

Słowa kluczowe: samorządy lokalne; reforma podatków lokalnych; dotacje państwowe; wyniki publiczne.

\section{Introduction}

As explained by President Emmanuel Macron at the congress for the mayors of France in November 2019, “equality does not apply only to women and men, but also to the local authorities, [it is necessary that] the Republic brings the same attention to our capital as to our villages (...) and to large cities as to medium-sized cities". This position - oh so political on the eve of the next municipal elections - shows that the local authorities are essential to the daily life of the French and that the question of local finances is a sensitive subject.

Local communities have not always had this importance, however ${ }^{1}$. At the time of the French Revolution in 1789, the communes and departments were given few powers and had no power to fix taxes. This is explained by the liberal ideology which was that of the revolutionaries. Public figures were not to intervene in the economy and the economic market was to balance itself ${ }^{2}$.

This way of understanding of the role of local authorities would not change until the 20th century with the development of the Keynesian state. From the 1970s and especially the 1980s, the communes, departments, and regions would exercise ever more numerous powers, and would be authorized to vote on a rate of local taxes. The grouping of municipalities would also be encouraged by the granting of tax powers.

1 E. Moysan, Les compétences financières locales dans le système juridique français, thèse pour le doctorat, Bibliothèque de finances publiques et fiscalité, tome 61, LGDJ, 2015, p. 23.

2 According to classical liberal ideology and in particular the physiocrats, who directly influenced the decision-makers of the Revolution. 
Today local authorities represent a significant part of the public sector. They in fact account for almost $20 \%$ of public expenditure ${ }^{3}$; local taxes represent $6.4 \%$ of $\mathrm{GDP}^{4}$, it being understood that local authorities are responsible for $9 \%$ of French public debt. These figures are important because they are taken into account in French data which make it possible to ensure that France respects the criteria laid down by European law in matters of public debt ${ }^{5}$. The Maastricht Treaty of 1992 imposed a deficit of less than $3 \%$ of GDP and a public debt of less than $60 \%$ of $\mathrm{GDP}^{6}$. However, the Treaty on the Functioning of the European Union indicates that "the word public means: that which relates to the general government, that is to say, central administrations, regional or local authorities and social security funds, excluding commercial transactions, as defined in the European system of integrated economic accounts”7.

The aim of the study is to show how local finances are a minor, but nevertheless - essential, component of the French public financial system. The study of recent financial reforms shows that local authorities are at the heart of the current challenges of French public finances. Their fiscal powers are diminishing, as are state subsidies. However, they remain a well-managed public sector.

\section{Local finances, a determining component of the French public financial system}

Local and regional authorities are legal persons distinct from the State under public law. These are municipalities, departments, regions, communities with special status, and overseas communities ${ }^{8}$. They benefit from

3 This article is based on figures from Institut National de la Statistique et des Études Économiques (INSEE) and the 2019 Observatory of Local Finances and Public Management report.

4 Compulsory levies represent 45\% of GDP in France.

5 M. Leroy, Quelle qualité de la décision financière des collectivités territoriales?, "Revue Française de Finances Publiques” 2019, No 148, p. 209.

6 Protocol No 12 on the excessive deficit procedure, Article 1.

Ibidem.

8 Article 72 of the Constitution of 4 October 1958. 
a certain legal and patrimonial autonomy which allows them to assume competences which are specific to them. It is the Parliament which defines these issues, as France is a decentralized unitary country ${ }^{9}$.

Municipalities benefit from a "general jurisdiction clause" under which they have a capacity for general intervention, without being limited by a list previously established by law. They, therefore, act in all matters of municipal interest. The main municipal powers are town planning, housing, the environment, and school management.

On the other hand, the regions and the departments exercise specialized powers ${ }^{10}$. The departments are mainly responsible for social action (children, the disabled and the elderly), infrastructure (such as roads and ports), and the management of middle-level schools. The regions are responsible for economic development, town and country planning, nonurban transport, high school management, and vocational training.

In addition to the municipalities, departments, and regions, there are structures grouping the municipalities: the public establishments for intermunicipal cooperation, which exercise compulsory powers and powers transferred by their member municipalities. In 2019, out of 34,979 municipalities, only four did not belong to a public establishment for intermunicipal cooperation ${ }^{11}$.

Despite the large number of local structures and the number of powers taken over, local finances indicated a budget surplus of 2.3 billion euros in 2018. This situation is explained by the fact that local authorities must respect the principle of a real equilibrium, imposed in $1982^{12}$. Article L. 1612-4 of the general code of the local authorities provides that "the budget of the local authority is in real balance when the revenue and expenditure of the two sections of the budget, revenue, and expenditure hav-

\footnotetext{
Article 1 of the Constitution of 4 October 1958.

10 N. Ferreira, La loi NOTRe : l'enchevêtrement des compétences, suite et ... fin ? , “Actualité Juridique. Collectivités Territoriales” 2016, p. 79.

11 General Directorate of Local Authorities, Statistical review of EPCIs with their own taxation as of 1 January 2020, February 2020, p. 2, https://www.collectiviteslocales.gouv.fr/files/files/dgcl_v2/DESL/Bilansstats2020/bilan-statistique-2020_diffusion.pdf (access on-line: 2.02.2020).

12 Law No 82-213 of 2 March 1982 relating to the rights and freedoms of the communes, the departments and the regions.
} 
ing been evaluated in an honest manner”. Each section of the budget must be adopted in balance ${ }^{13}$. Furthermore, this balance must be real, that is to say that the expenditure should not be underestimated and the revenue overestimated. A budget whose equilibrium has been achieved is, therefore, not in a state of equilibrium simply by the recording a revenue of subsidies whose allocation was not certain, and of loans whose conclusion was unlikely, given the very high debt level of the municipality ${ }^{14}$.

The law of 2 March 1982 created a financial judge - the regional chambers of accounts, which is responsible for monitoring the communities to ensure that they respect their financial obligations. These judges ensure that local authorities vote on their budgets within the deadlines set by law, do not fail to include compulsory expenditure in their budgets, and that they vote for their budgets in balance.

All these elements explain why local finances are well-managed. However, they are suffering from a reduction in government revenue, which reflects an increasingly difficult budgetary context, in which they constitute an important issue.

\section{Local finance, at the heart of the current challenges of French public finance}

In the last quarter of 2019, French public debt exceeded 100\% of GDP. The deficit, meanwhile, exceeds 3\% of GDP. If the local sector is in good financial health, it suffers from this situation which leads the State to reform local taxation and to reduce its financial aid to the local sector ${ }^{15}$. In order to maintain their position as the leading public investor and to present themselves as efficient entities, the local authorities have chosen to use management methods used by the private sector.

13 The investment section includes revenue and expenses for equipment, the operating section includes revenue and expenses to operate equipment.

14 Conseil d’État, 16 March 2001, Commune de Rennes-les-Bains c/ Lacan, queries No 160257 et 157128.

15 P. Hernu, Pour une gouvernance et une régulation systémique des finances des collectivités locales, “Gestion et Finances Publiques” 2019, No 5, p. 16. 


\subsection{The reform of local taxation imposed by the State}

Local taxation consists mainly of direct taxes, that is to say those paid directly by taxpayers to the tax authorities. There are four such taxes: the housing tax, the property tax on built properties, the property tax on undeveloped properties, and the territorial economic contribution.

Local taxation is disputed for its weight and the inequality it would generate between taxpayers. Of these local taxes, the one that is the most debated is the housing tax which represents about $20 \%$ of the total amount of direct local taxes, or about 22.7 billion euros in 2018 and whose product, since 1 January 2011, is assigned to the municipalities ${ }^{16}$. This tax is due from any occupant, owner, or tenant of a room for residential use on 1 January of the year, provided that this room is furnished. The tax is calculated by application to the rental value of the tax rate voted by the municipality. The 2018 finance law establishes, subject to an income, a reduction of the housing tax due for main residences ${ }^{17}$. This reduction should allow exempt about $80 \%$ of households from the payment of this tax in three years.

Despite this reform, this tax has continued to be criticized. It is, indeed, the heir to the movable contribution created by the law of 13 January and of 18 February 1791. It is based on the value of the real property occupied by the liable party. However, this value has not been updated since the 1970s. An update today would lead to a significant increase in values and, therefore, in the tax due. This was not the political choice that was made. The gradual abolition of the housing tax on the main properties will however result in a shortfall for the municipalities. The finance law for 2020 provides that a portion of a property tax on built properties currently collected by the departments (14.1 billion euros in 2018) will now be paid to the municipalities ${ }^{18}$. The state will share the

\footnotetext{
Finance law No 2009-1673 of 30 December 2009 for 2010.

Article 5 of the Law No 2017-1837 of 30 December 2017 of finances for 2018.

Article 5 of the Law No 2019-1479 of 29 December 2019 of finances for 2020.
} 
revenue from its main expenditure tax (TVA) with the inter-municipal authorities and departments ${ }^{19}$.

The recent reform of local taxation therefore leads to a new division of fiscal powers. The fear of elected officials is that the revenues intended to compensate for the abolition of this tax are not enough ${ }^{20}$. This matter is even more sensitive issue since at the same time state subsidies are decreasing.

\subsection{The decrease in endowments paid by the State}

In 2020, the total state subsidies to communities should amount to 38 billion euros ${ }^{21}$. This figure has been constantly decreasing since 2015, when it amounted to 47 billion euros. The state grants to local authorities are numerous, but the most important is the overall operating grant. It represented 26.9 billion euros in 2019, while in 2015 it amounted to 36 billion euros.

The global operating grant was created by a law of 3 January 1979, which created a global grant for municipalities, departments, and regions. Since 1993, it has also been paid to inter-municipal structures. Following the economic crisis of 2007-2008, the state decided to decrease this local revenue, in order to limit its own expenses, but also to encourage communities to spend less. In the same way, the public finance programming law for 2018-2022 provides for a national target for the development of local public expenditure (1.2\%) and sets targets for the development of public expenditure for each type of public administrations ${ }^{22}$.

However, as we have seen previously, local authorities have many powers. Several solutions are available to them to exercise these powers,

\footnotetext{
Ibidem.

20 P. Hernu, L'érosion continue de l'autonomie fiscale et financière des collectivités locales, “Gestion et Finances Publiques” 2019, No 1, p. 29.

21 Article 16 of the public finance programming law for the years 2018 to 2022.

22 Article 8 of the public finance programming law for the years 2018 to 2022.
} 
despite the reduction of state subsidies ${ }^{23}$. First, they can raise taxes. They have been allowed to do this by the law of 10 January 1980 which authorizes them to vote on the rate of the four local direct taxes (housing tax, two property taxes, and professional tax) ${ }^{24}$. The legislators, however, limited this possibility by not allowing to establish too big differences between the communes, and between the taxes paid by individuals and those paid by companies. However, this solution is limited for several reasons. On the one hand, since 2010, the state has reduced local fiscal powers by replacing the business tax with a national tax, so half of the base is entirely determined by Parliament ${ }^{25}$. Moreover, today only the municipalities can still vote on the local tax rate. On the other hand, as we have seen, the housing tax is disappearing.

Then, communities can borrow money from banks ${ }^{26}$. This possibility was offered to them by the legislator in the 19th century, and then was extended by the law of 2 March 1982. Henceforth the bank, the rate, and the amount of the loan are freely chosen by the community. Loan decisions simply need to be published and forwarded to the state official. There are only two conditions: this competence can only be exercised to cover equipment costs and its reimbursement constitutes a compulsory expenditure. However, this competence has sometimes been misused and has led communities to accept toxic loans ${ }^{27}$. These are loans that take the form of structured products, that is to say composed of several elements, each of them is changing according to conditions linked to the evolution of the financial markets. However, the indexing values of these different

23 E. Portal, Comment le bloc communal maîtrise-t-il ses dépenses de fonctionnement pour faire face à la contrainte budgétaire initiée par l'État?, "Revue Française de Finances Publiques” 2019, No 145, p. 299.

24 Article 1 of Law No 80-10 of 10 January 1980 on the adjustment of local direct taxation.

25 The professional tax has been replaced by the territorial economic contribution, made up of the land assessment of companies (the rate of which is set by the municipalities) and the contribution on the added value of businesses (the rate of which is set by Parliament).

26 For more developments on local borrowing, we refer to P. Salen, L'emprunt des collectivités territoriales : un paradoxe du droit public financier, thèse pour le doctorat, Bibliothèque de finances publiques et fiscalité, tome 60, LGDJ, 2014.

27 E. Fruchard, Après les emprunts toxiques, comprendre les contrats de prêts aux collectivités locales, Paryż, Voiron 2012. 
elements are very risky, for example the price of a raw material or that of a foreign currency. After the subprime crisis of 2008, some communities saw the amount of their interest rate increase very significantly ${ }^{28}$. The State therefore intervened to help these communities and to better regulate the use of local loans.

Also, the solution to finance local public services in spite of the tight budgeting perhaps lies rather in the performance of the local public management.

\section{Performance, at the heart of local public management}

Since the 1980s, local authorities have been a laboratory for modernized public management, which moreover inspired the State on the occasion of the organic law relating to the finance laws of 1 August 2001. This is explained by the fact that communities use tools inspired by the private sector. We can see this as a process of bringing local financial skills closer to the private sector, which "tends to be part of the problem of the efficiency and effectiveness of public action" ${ }^{29}$, by borrowing its "intellectual models"30.

As we have seen, since 1982, communities have borrowed money under the same conditions as businesses have been doing it. They can take out a loan directly on the financial markets via the issue of bonds, even if this process remains relatively marginal. Much more commonly, communities can go to the bank of their choice to apply for a loan. The choice of tools offered to them varies to the great extend: they may be fixed rate loans, variable, or even exchange rate techniques ${ }^{31}$.

28 See, for example, the report on risky financial products subscribed by local public actors, National Assembly, 2012.

29 F.-X. Merrien, De la gouvernance et des États-providence contemporains, "Revue Internationale des Sciences Sociales” 1998, No 155, p. 62.

30 J. Caillosse, Questions sur l'identité juridique de la gouvernance [in:] R. Pasquier, V. Simoulin, J. Weisbein (eds), La gouvernance territoriale. Pratiques, discours et théorie, Paryż, LGDJ, Coll. Droit et société, 2007, p. 61.

31 E. Portal, Analyse qualitative de l'offre de financement désintermédiée proposée aux collectivités locales, "Revue Française de Finances Publiques" 2020, No 149, p. 257. 
In addition, local accounting is also inspired by private sector methods ${ }^{32}$. It is based on accrual accounting. Transactions are taken into account for the financial year to which they relate, regardless of their date of payment or collection. This new practice leads communities to retrace, through their accounting entries, their financial flows, and to produce a statement of their assets, as well as a balance sheet. Communities must also ensure the use of caution. Concretely, they have an obligation to practice depreciation which includes the depreciation of assets as well as provisions intended to deal with risky operations. Finally, they must present regular, honest accounts giving a true picture of their assets and their financial situation. More recently, legislators have set up an experiment in the certification of local government accounts ${ }^{33} .26$ communities are participating in this experiment which is being carried out by the Court of Auditors. The first certification exercise will take place in 2020. It will give rise to an assessment which could result in an adoption of this system ${ }^{34}$.

Finally, community funding has been influenced by this logic. Communities are financed not only by tax and debt, but also by non-tax revenue. This is the case for fees which correspond to the payment for a local public service rendered to a user. Local authorities are authorized to assess the price of their services as closely as possible, taking into account the direct and indirect costs they bear to produce them, without seeking to make any profit. This is the case, for example, when they charge for the public waste collection service.

All these examples show that performance and the logic of results are at the heart of local public management, which is explained by a general movement of declining revenues and shrinking state. However, communities remain an essential sector in the eyes of citizens, hence their concern to manage themselves well and to be particularly efficient in the use of

32 S. Jeannard, La comptabilité publique locale. Quelles transformations? Quels enjeux?, "Revue Française de Finances Publiques” 2012, No 119, p. 103.

33 Law No 2015-991 of 7 August 2015 on the new territorial organization of the Republic.

34 L. Guyon, La certification des comptes des collectivités: Quelles finalités?, "Revue Française de Finances Publiques” 2019, No 145, p. 31. 
public funds. This is one of the main lessons they have learned from state decentralization since the 1980s.

\section{Bibliography:}

Caillosse J., Questions sur l'identité juridique de la gouvernance [in:] R. Pasquier, V. Simoulin, J. Weisbein (eds), La gouvernance territoriale. Pratiques, discours et théorie, LGDJ, Paryż 2007.

Ferreira N., La loi NOTRe: l'enchevêtrement des compétences, suite et ... fin?, “Actualité Juridique. Collectivités Territoriales” 2016, pp. 79-82.

Fruchard E., Après les emprunts toxiques, comprendre les contrats de prêts aux collectivités locales, Paryż, Voiron, 2012.

Guyon L., La certification des comptes des collectivités : Quelles finalités?, "Revue Française de Finances Publiques” 2019, No 145, pp. 31-43.

Hernu P., Pour une gouvernance et une régulation systémique des finances des collectivités locales, “Gestion et Finances Publiques” 2019, No 5, pp. 16-24.

Jeannard S., La comptabilité publique locale. Quelles transformations? Quels enjeux?, "Revue Française de Finances Publiques” 2012, No 119, pp. 103-113.

Leroy M., Quelle qualité de la décision financière des collectivités territoriales?, "Revue Française de Finances Publiques” 2019, No 148, pp. 209-244.

Merrien F.-X., De la gouvernance et des États-providence contemporains, "Revue Internationale des Sciences Sociales” 1998, No 155, pp. 61-72.

Moysan E., Les compétences financières locales dans le système juridique français, thèse pour le doctorat, Bibliothèque de finances publiques et fiscalité, tome 61, LGDJ, 2015.

Portal E., Analyse qualitative de l'offre de financement désintermédiée proposée aux collectivités locales, "Revue Française de Finances Publiques” 2020, No 149, pp. 257-269.

Portal E., Comment le bloc communal maîtrise-t-il ses dépenses de fonctionnement pour faire face à la contrainte budgétaire initiée par l'État ?, "Revue Française de Finances Publiques” 2019, No 145, pp. 299-311.

Salen P., L'emprunt des collectivités territoriales: un paradoxe du droit public financier, thèse pour le doctorat, Bibliothèque de finances publiques et fiscalité, tome 60, LGDJ, 2014. 